EGU2020-5688

https://doi.org/10.5194/egusphere-egu2020-5688

EGU General Assembly 2020

(c) Author(s) 2021. This work is distributed under

the Creative Commons Attribution 4.0 License.

\title{
Constraining the geometry at depth of La Maladeta and Andorra- Mont Louis granites (Central Pyrenees) through gravity modelling
}

\author{
Conxi Ayala ${ }^{1}$, Pilar Clariana ${ }^{2}$, Ruth Soto ${ }^{2}$, Joan Martí ${ }^{3}$, Aina Margalef ${ }^{4}$, Emilio Pueyo ${ }^{2}$, Félix Rubio ${ }^{5}$, \\ Carmen Rey-Moral ${ }^{5}$, Nuria Bach ${ }^{3}$, Stefania Schamuells ${ }^{3}$, and Jordi Cirés ${ }^{6}$ \\ ${ }^{1}$ Instituto Geológico y Minero de España (IGME), Geophysics and Remote Sensing, Madrid, Spain (c.ayala@igme.es), now \\ visiting the Institute of Earth Sciences Jaume Almera-CSIC \\ ${ }^{2}$ Instituto Geológico y Minero de España (IGME). Unidad de Zaragoza, 50006 Zaragoza, Spain \\ ${ }^{3}$ Institute of Earth Sciences Jaume Almera-CSIC, 08028 Barcelona, Spain \\ ${ }^{4}$ CENMA. Institut d'Estudis Andorrans (IEA), Andorra \\ ${ }^{5}$ Instituto Geológico y Minero de España, 28003 Madrid, Spain \\ ${ }^{6}$ Institut Cartogràfic i Geològic de Catalunya, Barcelona, Spain
}

In the Central Pyrenees, where density contrast between the Paleozoic rocks and the intruded granitic bodies is measurable, geological cross-sections constrained with gravity data help to unravel the subsurface geometry of the granites.

With this goal in mind, during 2018 and 2019 several gravimetric surveys were carried out in the Central Pyrenees to improve the existent spatial resolution of the gravity data from the databases of the Spanish and Catalan Geological Surveys, especially in La Maladeta and Andorra Mont-Louis granites' area. After the gravity reductions, we obtained the Bouguer gravity anomaly from which we calculated the residual gravity anomaly by subtracting a third degree polynomial which represents the regional anomaly in agreement with the geometry of the crust in this region.

The gravimetric response over La Maladeta and Andorra Mont-Louis granites is markedly dissimilar pointing out differences in the composition and geometry at depth of the two granites. La Maladeta granite shows a gravimetric zonation with small variations in its amplitude from one zone to the next, consistent with small lateral changes in its composition, predominantly granodioritic. By contrast, the Andorra Mont-Louis pluton is characterized by a relative minimum suggesting a more granitic composition.

With respect to the inferred geometry at depth, the results obtained from gravity modelling show that the La Maladeta granite displays a laccolithic shape with its basal contact deeping to the North whereas the Andorra Mont-Louis granite has a more batholitic shape. Although the emplacement age of both granites is similar (Late Carboniferous - Early Permian), their different geometry at depth suggests that either (1) their emplacement mechanisms were different or (2) the subsequent Alpine orogeny affected both granites in different ways better preserving the original geometry of the Andorra Mont-Louis granite. 
